University of Rhode Island

DigitalCommons@URI

Mechanical, Industrial \& Systems Engineering

Faculty Publications

Mechanical, Industrial \& Systems Engineering

2017

\title{
PDMS Flow Cell for Monitoring Bacterial Adhesion Capacity of Escherichia coli 0157:H7 in Beverages
}

Assem Abolmaaty

D.M.L. Meyer

University of Rhode Island, dmmeyer@uri.edu

Follow this and additional works at: https://digitalcommons.uri.edu/mcise_facpubs

Creative Commons License

c) (i)

This work is licensed under a Creative Commons Attribution 4.0 License.

\section{Citation/Publisher Attribution}

Abolmaaty, A., \& Meyer, D.M.L. (2018). PDMS Flow Cell for Monitoring Bacterial Adhesion Capacity of Escherichia coli 0157:H7 in Beverages. Journal of Advances in Biology \& Biotechnology, 15(4), 1-12. doi: 10.9734/JABB/2017/37682

Available at: http://dx.doi.org/10.9734/JABB/2017/37682

This Article is brought to you for free and open access by the Mechanical, Industrial \& Systems Engineering at DigitalCommons@URI. It has been accepted for inclusion in Mechanical, Industrial \& Systems Engineering Faculty Publications by an authorized administrator of DigitalCommons@URI. For more information, please contact digitalcommons-group@uri.edu. 


\title{
PDMS Flow Cell for Monitoring Bacterial Adhesion Capacity of Escherichia coli 0157:H7 in Beverages
}

\author{
Assem Abolmaaty $^{1^{*}}$ and D. M. L. Meyer ${ }^{2}$ \\ ${ }^{1}$ Department of Food Science, Faculty of Agriculture, Ain Shams University, Cairo, Egypt. \\ ${ }^{2}$ Department of Mechanical Engineering and Applied Mechanics, University of Rhode Island, \\ Kingston, RI 02881, USA.
}

Authors' contributions

This work was carried out in collaboration between both authors. Author AA designed the biological aspects, wrote the protocol, conduct experimental work, performed the statistical analysis and wrote the final draft of the manuscript. Author DMLM designed the engineering aspects for the PDMS fabrication and fluid flow system. Authors $A A$ and DMLM jointly collaborated in editing and reviewing experiments.

Article Information

DOI: $10.9734 / \mathrm{JABB} / 2017 / 37682$

Editor(s)

(1) Joana Chiang, Department of medical laboratory Science and Biotechnology, China Medical University, Taiwan.

Reviewers:

(1) Fatma Coskun, Namık Kemal University, Turkey. (2) Pushpa Prasad Acharya, Tribhuvan University, Nepal. (3) Evgeny Puchkov, Russian Academy of Sciences, Russia. Complete Peer review History: http://www.sciencedomain.org/review-history/21822

Original Research Article

Received $25^{\text {th }}$ October 2017 Accepted $6^{\text {th }}$ November 2017 Published $9^{\text {th }}$ November 2017

\section{ABSTRACT}

Aims: To develop and standardize a polydimethylsiloxane (PDMS) flow cells for monitoring bacterial adhesion capacity of biofilm formation by Escherichia coli O157:H7 in Beverages industry.

Study Design: PDMS chip was fabricated in house and placed in a metal chamber. The bioFerrograph generated different flow rates of bacterial cell suspension in the PDMS cells.

Methodology: PDMS flow cells were used to monitor bacteria adhesion capacity of $E$. coli O157:H7 inoculated into some beverages. The Effect of fluid flow rate and temperature on bacteria adhesion capacity was studied in order to standardize the system. Buffer system of adhesion was modified by varying the concentrations of PBS, Saline concentrations and $\mathrm{PH}$ value. The impact of elapsing time and initial number of bacterial cells were investigated. Fluorescence imaging of biofilm formation was also captured.

Results: Bacterial adhesion capacity reached the maximum at $0.1 \mathrm{ml} / \mathrm{min}$ and then dramatically dropped down when fluid flow rate increases. Maximized adhesion capacity occurred with a buffer 
system of $0.01 \mathrm{M}$ Phosphate buffer, $1.0 \% \mathrm{NaCl}, \mathrm{pH} 7.5$ at $30^{\circ} \mathrm{C}$. A complete linear relationship $\left(\mathrm{R}^{2}\right.$; $0.9956-0.9815)$ occurred between adhesion capacity of $E$. coli $\mathrm{O} 157: \mathrm{H} 7$ cells and elapsing time of food beverage. This linear relationship would help to predict and study biofilm formation in fluid and beverage industry. Maximum adhesion capacity occurred with beverages at the following order: skim milk followed by apple juice and then grape juice.

Conclusion: PDMS flow cell enables non-destructive, in situ investigation of bacteria adhesion capacity as an initial step for biofilm formation in real time under a wide range of flow rates, nutrient conditions, fluid temperature, and elapsing times. It is inexpensive, simple, disposable, easy-to-use, and can accurately mimic the dynamic flow conditions in beverage industry.

Keywords: Bacterial adhesion Capacity; biofilm-forming Bacteria; polydimethylsiloxane (PDMS); flow cell; E. coli O157:H7; Beverages; Bio-Ferrograph.

\section{INTRODUCTION}

Biofilm provide good environment to hides and protects pathogens. Bacteria attached and form biofilm are often resistant to disinfection and responsible for the contamination of industrial processes including fluid transport, wastewater management, food industry, and medical implants [1,2]. Poor sanitation of food contact surfaces, equipment, and processing environments has contributed to spread bacterial biofilms, which may contain pathogenic microorganisms. Many types of foodborne disease outbreaks are associated with biofilm especially those involving Listeria monocytogenes [3-5], Salmonella [6,4], and E. coli $\quad$ 157:H7 [7,8]. Produce-associated outbreaks were first reported in 1991 [9] including apple juice, milk, and grape juice. They have remained a prominent food vehicle, accounting for $34 \%$ of foodborne outbreakrelated cases [9-14]. In 2012, unpasteurized apple juice has caused $E$. coli outbreaks in Michigan

(https://foodpoisoningbulletin.com/2012/michigan -e-coli-cases-linked-to-unpasteurized-cider/).

Another outbreak occurred in Canada with $E$. coli infections linked to the unpasteurized beverage (https://foodpoisoningbulletin.com/2014/e-coliillnesses-prompt-recall-of-unpasteurized-applecider-in-canada/). Lately, outbreaks associated with unpasteurized milk has significantly increased in the United States during the period; 2007-2012 [15].

Centers for Disease Control and Prevention (CDC) estimate that $65 \%$ of human bacterial infections involve biofilms [16]. Small numbers of surviving organisms can regrow, damaging beverage and dairy products. This might destroy a company's reputation in the event of a product recall due to negative health outcomes [17]. In beverages industry, biofilm forms at different surfaces specially the inner surface of pipelines. Biofilm consists of both microbes and their extracellular polymeric substances (EPS), usually polysaccharides [18]. EPS facilitate the initial attachment of bacterial cells to the surface, maintain biofilm structure, and enhance biofilm resistance to anti-microbial agents [19]. Adhesion of bacterial cells is a time dependent process and divided into two phases: the reversible and the irreversible [19]. Microorganisms first bind reversibly to the organic matter and then irreversible with their flagella and fimbriae. Adhesion of bacterial cells to a surface is influenced by the following factors: $\mathrm{pH}$, temperature, cell hydrophobicity, cell surface charge, motility, cell structure including EPS and flagella, ionic concentration, the growth phase and nutrient content [20].

Biofilm formation in tubes and packaging material used in the food industry and others have become of great interest. Available methods for measuring bacterial adhesion and biofilm formation are important tools in monitoring foodborne pathogens in beverage and medical industry. Measurement of bacterial adhesion and biofilm formation is however, not straightforward. The reason behind that is the difficulty to generate and maintain a fluid flow environment along with controlling growth conditions. Microtiter plates based methods have become the routine assay for biofilm forming bacterial in medical field and food industry [21]. However, they are vulnerable and inaccurate for quantitative evaluation of bacterial adhesion and surface colonization [22]. Microtiter plates based methods do not provide an accurate mimicking of the dynamic flow situation and they lack control over experimental conditions. Therefore, difficult to compare between groups. Biofilm formation under dynamic fluid flow conditions [23] and the rheological behavior of biofilms have become of great interest [24]. There are disadvantages of 
using available fluid flow devices; to list a few: amaterials incorporated into flow cells cannot be autoclaved, b- left over residual debris of previous experiments often causes contamination [25], c- destructive methods such as sonication are often required to remove multicellular structures of biofilm.

In our previous work, quantification of biofilms was successfully measured under static conditions for different foodborne pathogens; Salmonella enteritidis, Listeria monocytogenes, and E. coli O157:H7 using PDMS chip biofilm assay [26]. Abolmaaty and Meyer [26] suggested that the large surface area available and the hydrophobic characteristic of the PDMS internal surfaces allowed the adsorption of hydrophobic targets such as bacterial cells and uniformly distribute them along the larger surface area of the channels. It was observed that the adhesion of microorganisms to PDMS channel was dramatically higher than microliter plates when nutrient in their surroundings become limited [20, 26]. The objective of this research was to standardize a Polydimethylsiloxane (PDMS) mini-fluidic chip assay and to evaluate cell adhesion, in which the device can be easily used as an inexpensive flow cell for quantitative monitoring and studying biofilm stages in beverage industry. E. coli O157:H7 was used for this study as a model of biofilm forming bacteria.

\section{MATERIALS AND METHODS}

\subsection{Fabrication of PDMS Chip}

The PDMS flow cell was fabricated from polydimethylsiloxane (PDMS) with the use of reusable master mold as described in our previous work [26]. The mold was fabricated with the aid of photo mask designed at the machine shop, Mechanical Engineering, University of Rhode Island. Polydimethylsiloxane (PDMS) we mixed thoroughly with a silicone elastomer curing agent $(10: 1 \mathrm{w} / \mathrm{w})$ and poured onto mold. The PDMS was degassed in a vacuum for five min and then the chamber was vented. The PDMS was backed at $90^{\circ} \mathrm{C}$ for $45 \mathrm{~min}$. After curing, the PDMS chip was peeled off of the mold and then a biopsy punch was used to make inlets and outlets. A metal chamber consisting of an upper and lower plate was custom made at the machine shop. Each plate contained holes for the screws in allowing the PDMS chip to be temporarily sealed with a removable glass plate. The upper plate of the chamber was designed with two openings allowing access to the inlets and outlets of the chip (Fig.1.c). Fig. 2 illustrates the schematic diagram of the PDMS flow cell showing the passing of cell suspension from media tank via bio-Ferrograph ( Fig. 1.a) to the inlet of PDMS flow cell and then to the outlet reservoir tank.

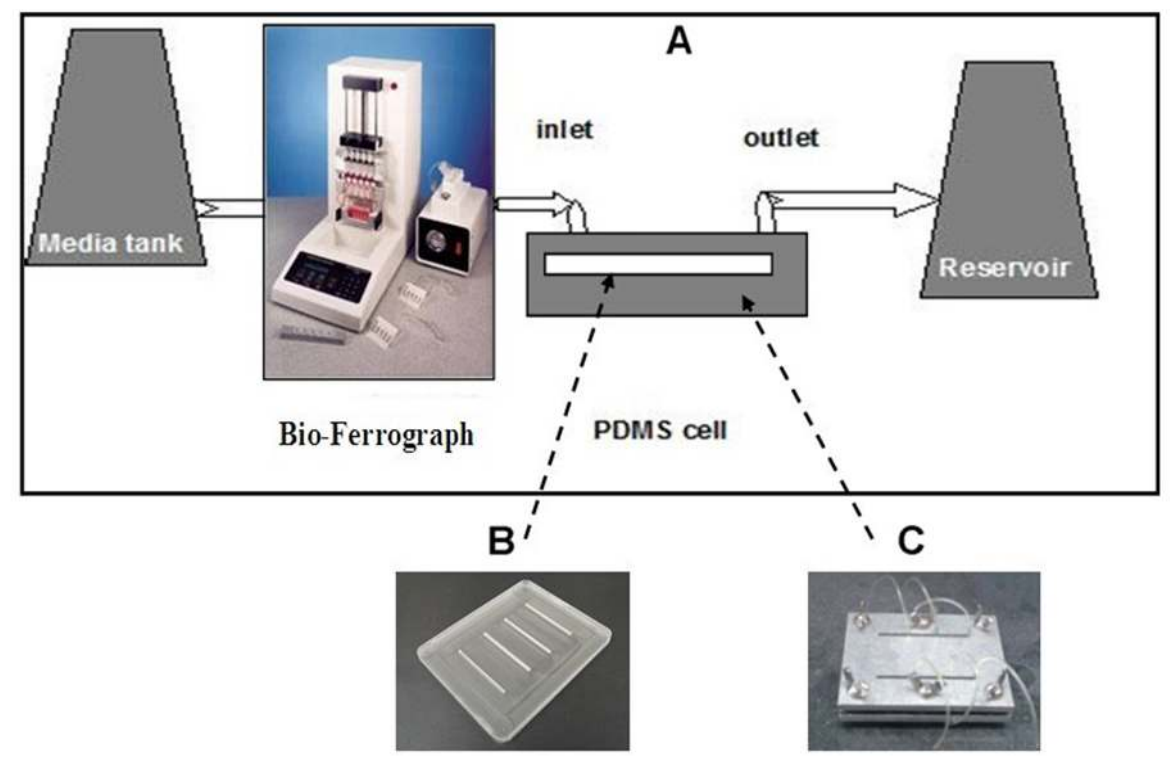

Fig. 1. PDMS cell flow system

Schematic diagram of the PDMS flow cell showing the passing of cell suspension from media tank via bioFerrograph to the inlet of PDMS flow cell $(B)$ covered with sterile glass plate and then placed in the metal chamber $(C)$ and then to the outlet reservoir tank. 


\subsection{Microorganism and Routine Cultivation}

Escherichia coli 0157:H7 strain $\mathrm{C9490}$ was obtained from the Centers for Disease Control, Atlanta GA 30333 and was routinely grown for $12 \mathrm{~h}$ in $100 \mathrm{ml}$ of Tryptic Soy Broth plus $0.5 \%$ dextrose (TSB+) at $37^{\circ} \mathrm{C}$ in $250 \mathrm{ml}$ baffled flasks with rotary agitation (200 rpm). Cells were harvested by centrifuging broth cultures at $16,000 \mathrm{~g}$ for $10 \mathrm{~min}$ at $4^{\circ} \mathrm{C}$. The cells were then resuspended in phosphate buffered PBS (PBS; $0.005 \mathrm{M}$ phosphate buffer plus $0.05 \% \mathrm{NaCl}, \mathrm{pH}$ 7.4) and diluted in PBS to achieve required cell densities unless otherwise stated. Exponentially growing cells $\left(\sim 1 \times 10^{9}\right.$ cells $\left./ \mathrm{ml}\right)$ were harvested by centrifuging broth cultures at $13,000 \mathrm{~g}$ for 10 min at $4^{\circ} \mathrm{C}$. Pellets were resuspended in sterile PBS, pelleted again and the concentration of cells was adjusted as required by re-suspending in either PBS or beverages as needed. Cell densities were determined with the use of Tryptic Soy Agar (TSA) plates (Difco, Detroit, Michigan). Plate counts were correlated with absorbance readings at $600 \mathrm{~nm}$ using Spectra Max 340.

\subsection{Effect of Fluid flow Rate on Bacteria Adhesion Capacity}

Bacterial adhesion to a surface, the initial step of biofilm formation is of particular interest. PDMS flow cell was prepared as follows: PDMS chip was aseptically washed with ethanol, air dried, covered with sterile glass plate and then placed in the metal chamber as described above. The effect of fluid flow rate on the adhesion of bacterial cells was studied by passing a cell suspension of $1 \times 10^{4}$ cells $/ \mathrm{ml}$ in PBS through the Mini-fluidic chips via the bio-ferrograph (Guilfoyle, Inc., Belmont, MA) at different flow rates $(0.004,0.008,0.01,0.04,0.08,0.1,0.2$, $0.4,0.6 \mathrm{ml} / \mathrm{min}$ ) for a constant passage time of $100 \mathrm{~min}$ at room temperature. The bio-ferrograph permitted extremely accurate control of the solutions flow rate through the minichannel. After each passage time was complete, unattached bacterial cells was washed out by passing PBS through the flow cell using bio-Ferrograph for 1 min. PDMS mini-channels were then filled with $200 \mu \mathrm{l}$ of TSB broth and incubated for $12 \mathrm{~h}$ at $37^{\circ} \mathrm{C}$. PDMS chips were made into two groups: first group for CFU measurement using plate counts and the second one for Crystal Violet (CV) staining. Each group was made in triplicates. To ensure that PDMS channels do not dry up during the incubation, they were placed in boxes, designed for $1 \mathrm{ml}$ automatic pipette tips that are partly filled with $5 \mathrm{ml}$ distilled water. Control samples were conducted in triplicates as described above by adding just $0.2 \mathrm{ml}$ of sterile TSB to the channels. After the incubation periods were complete, the glass plate was removed to open the PDMS chip. Planktonic bacterial medium was removed and PDMS channels were washed three times with $0.2 \mathrm{ml}$ sterile PBS to remove loosely associated bacteria. The biofilm was physically scrapped off using sterile spatula with the aid of hyaluronidase digestive enzyme and then collected into sterile PBS in $1.5 \mathrm{ml}$ Eppendorf tube. Hyaluronidase (MP Biomedicals, LLC, Solon OH) was prepared in PBS buffer at a different concentration $(2,4,8 \mathrm{mg} / \mathrm{ml})$ and tested for bacterial survivals. A cell suspension of $1 \times 10^{3}$ cells $/ \mathrm{ml}$ were incubated at $37^{\circ} \mathrm{C}$ for 30 min with 4 $\mathrm{mg} / \mathrm{ml}$ hyaluronidase. Survivals were determined with the use of Tryptic Soy Agar (TSA) plates. Serial dilutions of biofilm suspensions were prepared in sterile PBS and then $0.1 \mathrm{ml}$ of the dilution was smeared onto TSA plates. Plates were incubated for $12 \mathrm{~h}$ at $37^{\circ} \mathrm{C}$ for the determination of CFU. PDMS channels of the second group were air dried for $45 \mathrm{~min}$ and each well was stained with $150 \mu \mathrm{l}$ of $1 \%$ crystal violet (CV) solution in water for $45 \mathrm{~min}$ at room temperature. After staining, channels were washed with sterile distilled water three times. At this point, biofilms were visible as purple layer formed on the side of each channel. The quantitative analysis of biofilm production was performed by adding $220 \mu \mathrm{l}$ of $95 \%$ ethanol to destain the biofilm. Two Hundred microliters from each channel was transferred to a new microtiter plate and absorbance of the crystal violet present was measured at $595 \mathrm{~nm}$ using Spectra Max 340. All assays were performed in triplicates, means and standard errors were calculated for all repetitions of the experiment.

\subsection{Effect of Temperature on Bacterial Adhesion Capacity}

The driving forces of cell adhesion to the PDMS channels is based on the hydrophobic interaction between bacterial cell wall and the surface chemistry of the inner surface of the minichannels. Temperature might have an impact on the attachment of bacterial cells to the surface. The influences of the temperature during the passage period (100 min) was studied by passing $1 \times 10^{4}$ cells $/ \mathrm{ml}$ through the PDMS minichannels at different temperature $(5,10,15$, $20,25,30,35,40,45$ and $50^{\circ} \mathrm{C}$ ) using the bioFerrograph at the optimum flow rate which was obtained earlier $(0.1 \mathrm{ml} / \mathrm{min})$. After each passage 
time was completed, PDMS channels were washed with sterile PBS using bio-Ferrograph to remove bacteria loosely associated bacteria. PDMS mini-channels were then filled with $200 \mu \mathrm{l}$ of TSB broth and incubated for $12 \mathrm{~h}$ at $37^{\circ} \mathrm{C}$. Biofilm was measured using both plate counts and CV staining as described above.

\subsection{Effect of Buffer System on Cells Adhesion}

Hence, the buffer system might manipulate motility, cell hydrophobicity, ionic concentration, cell surface charge; the buffer system modified by varying the concentrations of PBS, saline concentrations and $\mathrm{pH}$ value. Experiments were conducted as stated earlier but with changing one variable at a time and tested for bacterial adhesion capacity.

\subsection{PDMS Flow Cell Application with Some Food Fluids}

Exponential growth of $E$. coli $0157: \mathrm{H} 7$ was harvested, washed as described above and adjusted to $1 \times 10^{4} \mathrm{cells} / \mathrm{ml}$ in sterile PBS. Different beverages (skim milk, apple juice, grape juice) were purchased from retail stores, distributed into $250 \mathrm{ml}$ flasks and then subjected to $15 \mathrm{~min}$ autoclaving at $121^{\circ} \mathrm{C}$. Beverages were then cooled down in ice and inoculated with $1 \mathrm{x}$ $10^{4} \mathrm{cells} / \mathrm{ml}$.

\subsubsection{Effect of elapsing time on cell adhesion}

The effect of elapsed time of beverage flow on the adhesion of bacterial cells to the inner surface of PDMS mini-channels was studied by passing each inoculated beverage at different times intervals $(5,10,15,20,30,40,60,80,100$, 120,150 , and $180 \mathrm{~min}$ ) using a Bio-Ferrograph at the optimum flow rate obtained earlier. After each passage was complete, PDMS flow cells were filled with $200 \mu \mathrm{l}$ of TSB broth and allowed for biofilm formation as stated above. The PDMS flow chips were divided into two groups: first group for the CFU determination of the biofilm using plate counts and the second group for Crystal Violet (CV) staining as described above.

\subsubsection{Effect of cell density in food fluids on bacterial adhesion}

The effect of varying cell density on bacterial adhesion to PDMS surface was studied as follows: different concentrations of $E$. coli
0157:H7 prepared in different beverages as mentioned above, ranging from 5 to $1 \times 10^{7}$ cells/ml, was introduced to PDMS flow cell using bio-Ferrograph at a flow rate of $0.1 \mathrm{ml} / \mathrm{min}$ for a constant passage time of $100 \mathrm{~min}$. Biofilm formation was then conducted for $12 \mathrm{~h}$ as mentioned above. The PDMS biofilm assay was performed in triplicate, means and standard errors were calculated for all repetitions of the experiments.

\subsubsection{Fluorescence imaging of biofilm formation}

Food fluids (skim milk, apple juice, grape juice) inoculated with bacterial cells was subjected to PDMS flow cells for $100 \mathrm{~min}$ as mentioned above. After the incubation period was complete, the medium was removed from each PDMS channel. PBS buffer containing $4 \mathrm{mg} / \mathrm{ml}$ hyaluronidase was introduced to the minichannels via bio-Ferrograph for $10 \mathrm{~min}$ at a flow rate of $0.1 \mathrm{ml} / \mathrm{min}$. This procedure would facilitate antigen antibody reaction with Anti-Escherichia coli 0157:H7. BacTrace Anti-Escherichia coli 0157:H7, FITC labeled, was obtained from KPL, Inc. Gaithersburg, Maryland and prepared in PBS buffer. Antibody was diluted to (1-64) and then added to corresponding channel. Channels were incubated for $60 \mathrm{~min}$ at $37^{\circ} \mathrm{C}$. After the incubation period was complete, channels were emptied from the antibodies and washed three times with sterile distilled water. Channels were examined under Epifluorescence microscope using $20 x$ lens.

\section{RESULTS AND DISCUSSION}

\subsection{Effect of Fluid Flow Rate on Cell Adhesion}

Biofilm is initiated when microorganisms first bind reversibly and then irreversible with their flagella and fimbriae. A cell suspension in PBS was used to study the attachment of bacterial cells to PDMS flow cell. Hyaluronidase found to render the biofilm during the scraping process, make it more detachable, and resulting in higher yield of biofilm. When different concentrations of hyaluronidase were studied with scraping biofilm, $4 \mathrm{mg} / \mathrm{ml}$ found to be the optimum concentration resulted in the maximum yield of biofilm when incubated at $37^{\circ} \mathrm{C}$ for $20 \mathrm{~min}$. $E$. coli 0157:H7cells survived in $4 \mathrm{mg} / \mathrm{ml}$ of Hyaluronidase in PBS at $37^{\circ} \mathrm{C}$ for $30 \mathrm{~min}$ (data are not shown). Hyaluronidase found to render 
tissue more readily permeable to injected fluids [27] and accelerates the passage of antibiotics from the circulation into the synovial fluid. It improves the systemic bioavailability of proteins [28].

The yield of biofilm measured by both CFU counts and $\mathrm{CV}$ indicated that maximum cell adhesion was achieved at low flow rates ranging from $(0.004-0.1 \mathrm{ml} / \mathrm{min})$ for $100 \mathrm{~min}$ via bioFerrograph (Fig. 2). The attachment of cells was then gradually reduced to reach the minimum at $0.6 \mathrm{ml} / \mathrm{min}$. It has been confirmed that the motility rates would highly influence the initiation of biofilm formation when cells are attached to the surface. Biofilm formation was dramatically reduced three folds when bio-Ferrograph adjustments elevated up from 0.1 to $0.6 \mathrm{ml} / \mathrm{nm}$ (Fig. 2).

\subsection{Effect of Temperature on Cells Adhesion}

Our data indicated that varying the adhesion temperature had a great impact on adhesion of bacterial cells when passing through PDMS surface at a flow rate of $0.1 \mathrm{ml} / \mathrm{min}$ for $100 \mathrm{~min}$ via bio-Ferrograph (Fig. 3). A bell shaped curve was generated with the yield of biofilm as a result of different adhesion temperatures of cell suspension. Both low adhesion temperature (5, 10 and $\left.10^{\circ} \mathrm{C}\right)$ and high $\left(45\right.$, and $50^{\circ} \mathrm{C}$ ) reported small yield of biofilm. Certainly, high and low adhesion temperature found to notably inhibit adhesion capacity while 25,30 , and $35^{\circ} \mathrm{C}$ yielded maximum and near maximum rates of adhesion capacity (Fig. 3).

\subsection{Effect of pH, Phosphate Buffer (PB) and $\mathrm{NaCl}$ Concentration on Bacterial Adhesion Capacity}

Maximum bacterial adhesion capacity occurred at $\mathrm{pH} 7.5$ when cell suspension was passed through the Mini-fluidic chips via the bioferrograph at $0.1 \mathrm{ml} / \mathrm{min}$ ) for a constant passage time of $100 \mathrm{~min}$ at room temperature. The adhesion rates were dramatically dropped down at both sides of the curve reporting no adhesion at $\mathrm{pH} 4$ (Fig. 4). We assessed the optimum PB concentration at $\mathrm{pH} 7.5$ with $0.05 \% \mathrm{NaCl}$ present with each buffer concentration and found that $0.01 \mathrm{M}$ PB elevated adhesion capacity to the maximum (Fig. 5). The concentration of $\mathrm{NaCl}$ found to be critical. Concentrations of 0.04 and $5 \% \mathrm{NaCl}$ found to notably inhibit adhesion capacity while $1.0 \%$ yielded maximum and near maximum rates of adhesion capacity (Fig. 6). Our data confirmed that buffer system has such great impact on initiation of biofilm formation.

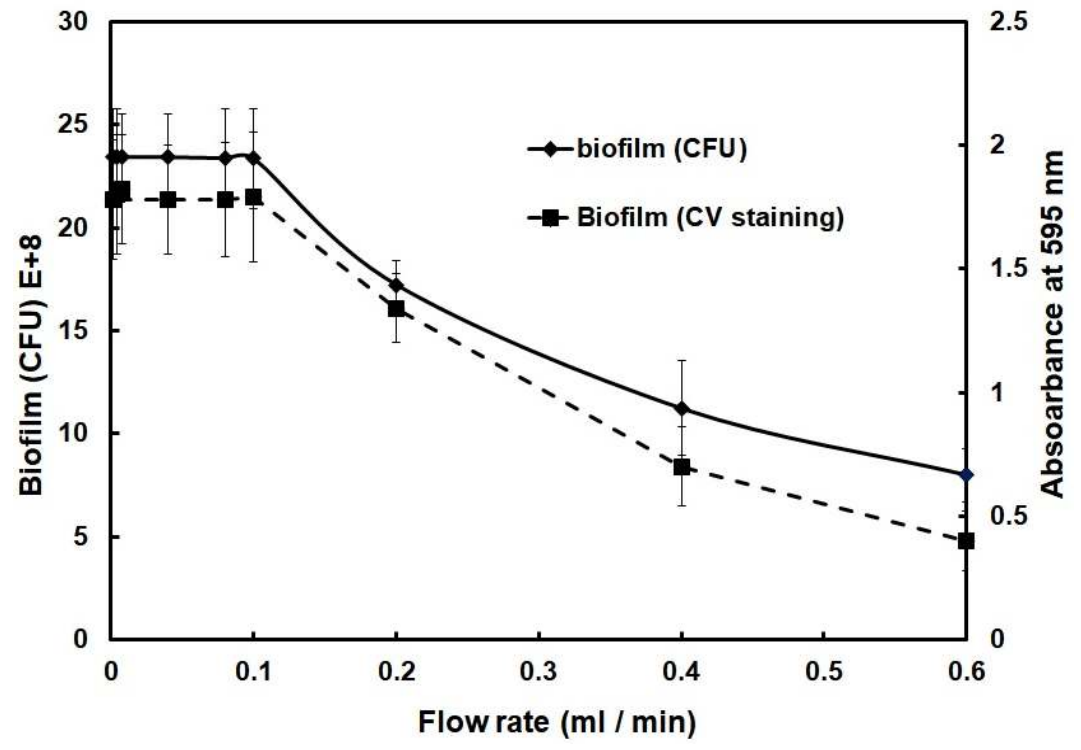

Fig. 2. Effect of fluid flow rate on bacteria adhesion capacity

A cell suspension of $1 \times 10^{4}$ cells / $\mathrm{ml}$ in PBS was passed through the Mini-fluidic chips via the bio-Ferrograph at different flow rates $(0.004,0.008,0.01,0.04,0.08,0.1,0.2,0.4,0.6 \mathrm{ml} / \mathrm{min})$ for a constant passage time of 100 min at room temperature. PDMS flow cells were filled with $200 \mu \mathrm{l} \mathrm{TSB}$. After $12 \mathrm{~h}$ of incubation at $37 \mathrm{C}$, the yield of biofilm were evaluated using plate counts (CFU) and Crystal Violet (CV) staining as mentioned above. 


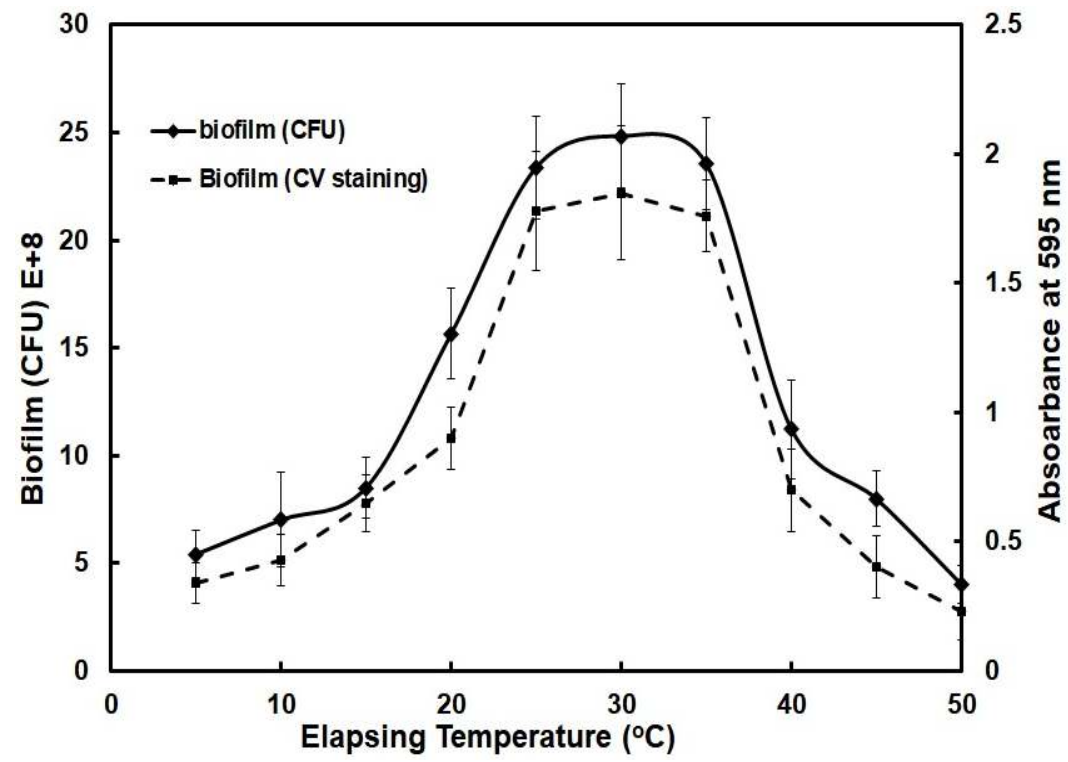

Fig. 3. Effect of temperature on bacterial adhesion capacity

A cell suspension of $1 \times 10^{4}$ cells / ml in PBS was passed through the Mini-fluidic chips via the bio-Ferrograph at $0.1 \mathrm{ml} / \mathrm{min})$ for a constant passage time of $100 \mathrm{~min}$ at different temperature $(5,10,15,20,25,30,35,40,45$ and $\left.50^{\circ} \mathrm{C}\right)$. PDMS flow cells were filled with $200 \mu \mathrm{l} \mathrm{TSB}$. After overnight incubation at $37^{\circ} \mathrm{C}$, the yield of biofilm was evaluated using plate counts (CFU) and Crystal Violet (CV) staining as mentioned above.

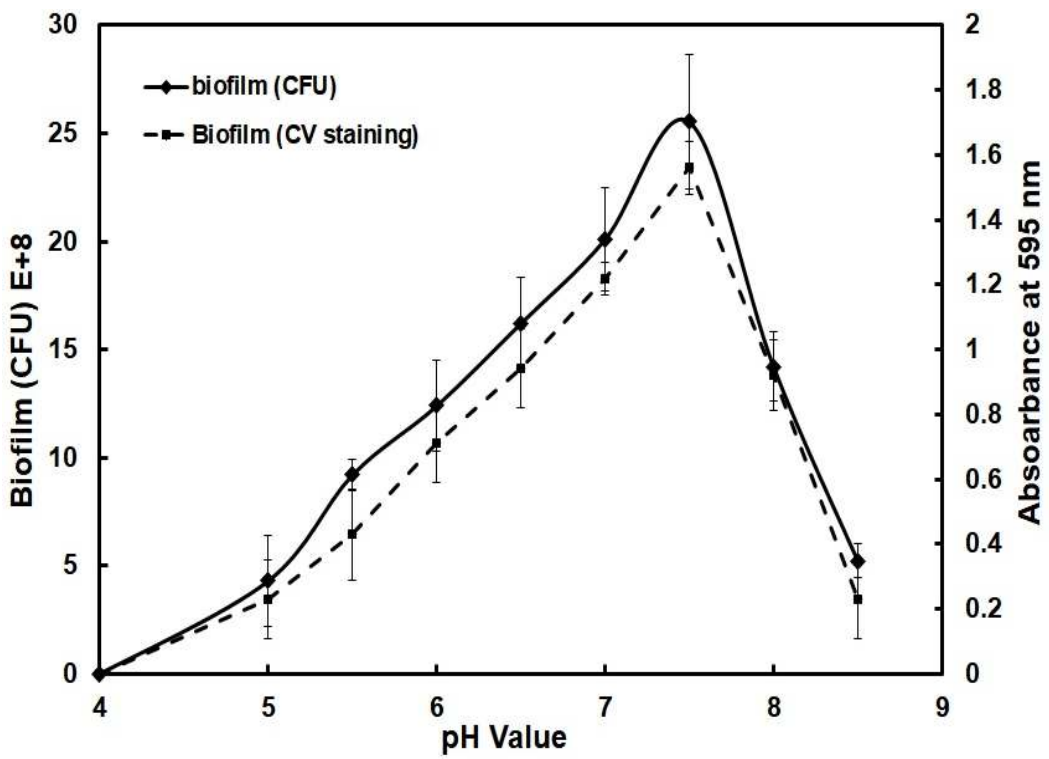

Fig. 4. Effect of pH on bacterial adhesion capacity

A cell suspension of $1 \times 10^{4}$ cells $/ \mathrm{ml}$ in various $P B S$ prepared at different $p H$ values $(4.0,5.0,5.5,6.0,6.5,7.0$, $7.5,8.0,8.5)$ was passed through the mini-fluidic chips via the bio-Ferrograph at $0.1 \mathrm{ml} / \mathrm{min}$ ) for a constant passage time of $100 \mathrm{~min}$ at room temperature. PDMS flow cells were filled with $200 \mu \mathrm{l} \mathrm{TSB}$. After $12 \mathrm{~h}$ of incubation at $37^{\circ}$, the yield of biofilm were evalu ated using plate counts (CFU) and Crystal Violet (CV) staining as mentioned above. 


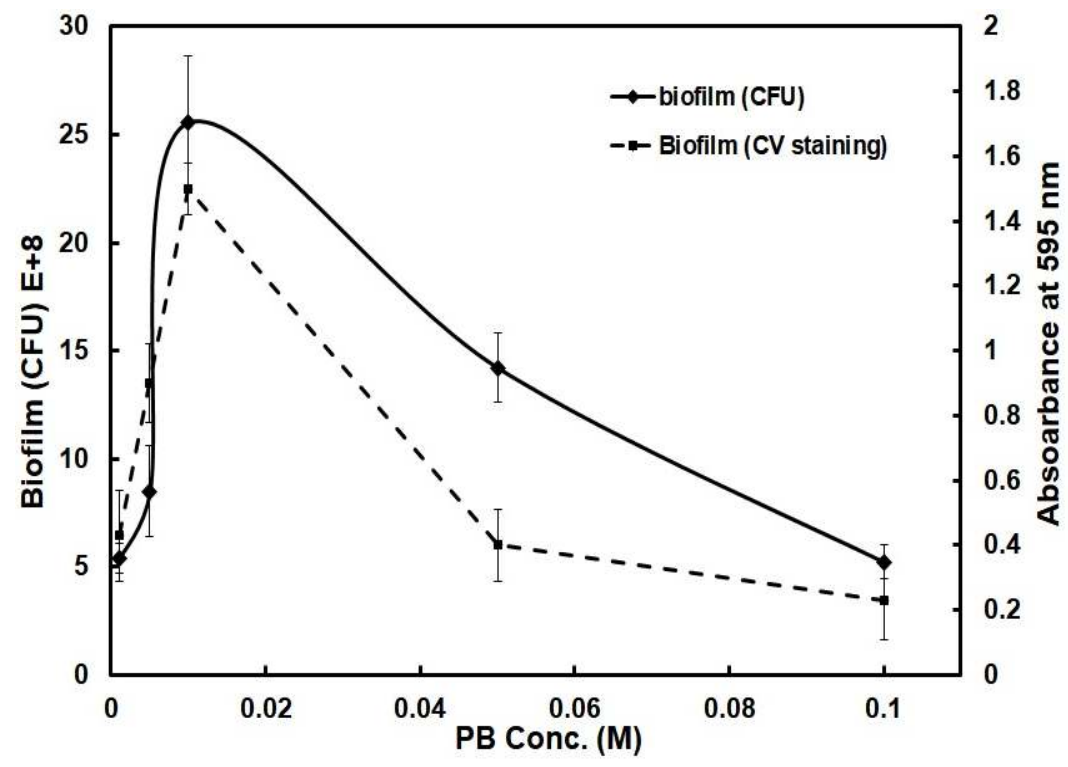

Fig. 5. Effect of phosphate buffer (PB) on bacterial adhesion capacity

A cell suspension of $1 \times 10^{4}$ cells $/ \mathrm{ml}$ in different concentration of phosphate buffer $(0.001,0.005,0.01,0.02$, $0.05,0.1 \mathrm{M}$ ) plus $0.85 \mathrm{NaCl}, \mathrm{pH} 7.4$, was passed through the mini-fluidic chips via the bio-Ferrograph at 0.1 $\mathrm{ml} / \mathrm{min}$ ) for a constant passage time of $100 \mathrm{~min}$ at room temperature. PDMS flow cells were filled with $200 \mu \mathrm{l}$ TSB. After $12 \mathrm{~h}$ of incubation at $37^{\circ} \mathrm{C}$, the yield of biofilm were evaluated using plate counts (CFU) and Crystal Violet (CV) staining as mentioned above.

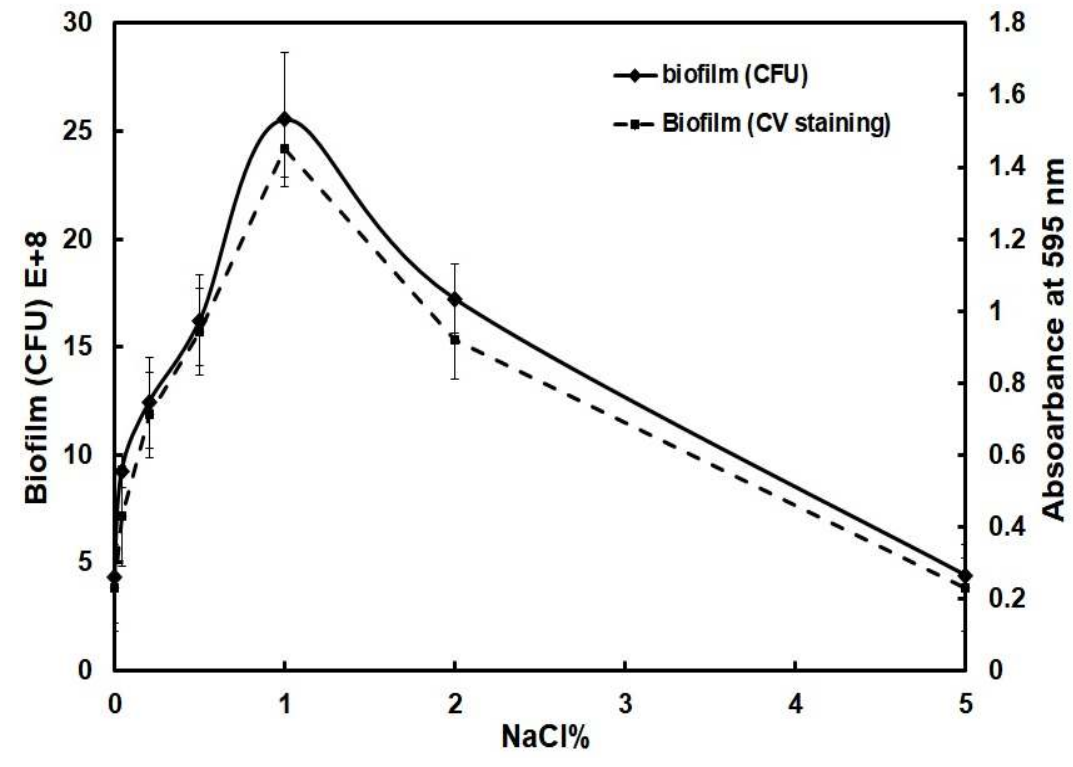

Fig. 6. Effect of $\mathrm{NaCl}$ concentration on bacterial adhesion capacity

A cell suspension of $1 \times 10^{4}$ cells $/ \mathrm{ml}$ in PBS prepared with different saline concentrations $(0.04,0.2,0.5,1.0$, 2.0, 5.0) at $\mathrm{pH} 7.4$ was passed through the mini-fluidic chips via the bio-Ferrograph at $0.1 \mathrm{ml} / \mathrm{min}$ ) for a constant passage time of $100 \mathrm{~min}$ at room temperature. PDMS flow cells were filled with $200 \mu \mathrm{l} \mathrm{TSB}$. After $12 \mathrm{~h}$ of incubation at $37^{\circ} \mathrm{C}$, the yield of biofilm were evaluated using plate counts (CFU) and Crystal Violet (CV) staining as mentioned above. 


\subsection{Effect of Different Elapsed Time of Food Fluids on Bacterial Adhesion Capacity}

This study was conducted to investigate the influences of nutrient composition and fluid food system on adhesion capacity. Three food fluids were selected (grape juice, milk, and apple juice), inoculated with $E$. coli $\mathrm{O} 157: \mathrm{H} 7$ and pumped via bio-Ferrograph into PDMS flow cell at a flow rate of $0.1 \mathrm{ml} / \mathrm{min}$ for different elapsing time $(5,10,15,20,30,40,60,80,100,120,150$, and $180 \mathrm{~min}$ ). Both total counts (CFU) and CV readings generated a wonderful linear pattern (Fig. 7) with a Correlation Coefficient of (0.9956 0.9815 ) between elapsing time and the yield of biofilm that was initiated from cell suspensions in skim milk, orange juice and apple juice. The highest yield biofilm formation was obtained from skim milk followed by apple juice and then grape juice. PDMS flow cell would be very beneficial to predict biofilm formation in beverage industry and other manufacture where pipelines are involved to transfer fluids throughout any process. PDMS flow cell is easy to design to mimic different surface and therefore tackle any biofilm surfaces.

\subsection{Effect of Various Number of $E$. coli 0157:H7 Cells Suspended in Food Fluids on Bacterial Adhesion Capacity}

Food fluids including grape juice, skim milk, and apple juice was inoculated with different concentration of bacterial cells. The bioFerrograph was used to deliver food fluids through PDMS flow cell at a constant flow rate of $0.1 \mathrm{ml} / \mathrm{min}$ for a constant passage time of 100 min. A proportional increase in biofilm yield was observed with the increase in cell densities, ranging from 5 to $1 \times 10^{7}$ cells $/ \mathrm{ml}$ (Fig.8) indicating that a PDMS chip can be a useful tool for quantitatively monitoring of biofilm development inside beverage pipelines. The highest yield was obtained from skim milk samples followed by apple juice and then grape juice (Fig. 8). The Power curve found to be a good key concept for understanding the relationship between initial number of cells attached to PDMS inner surface and biofilm formation measured as CFU and crystal violet. These data generated power equations as illustrated in Fig. 8 with Correlation Coefficients between $(0.86-0.94)$. Undoubtedly,

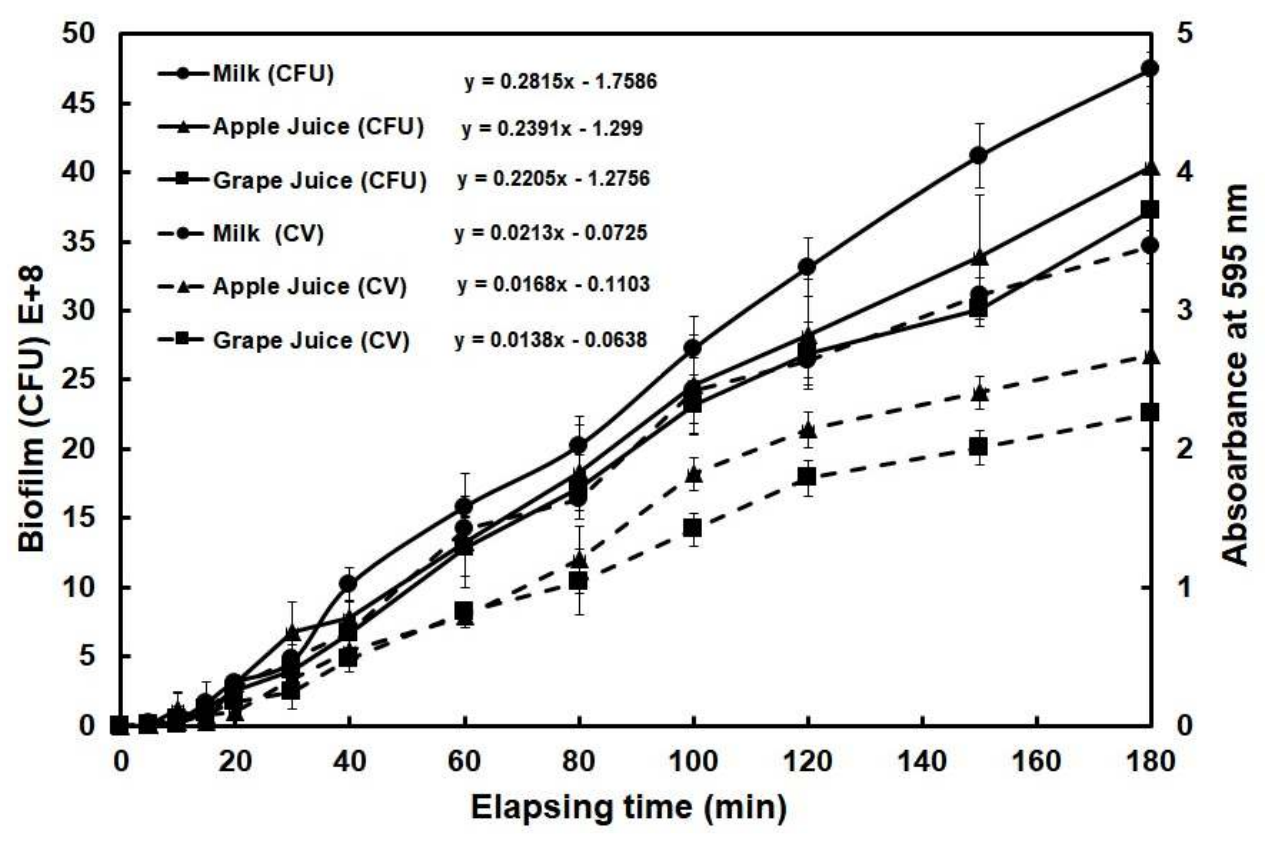

Fig. 7. bacterial adhesion capacity with different elapsed time of food fluids

A cell suspension of $1 \times 10^{4}$ cells $/ \mathrm{ml}$ in different sterile food fluids was each passed through the mini-fluidic chips via the bio-Ferrograph at $0.1 \mathrm{ml} / \mathrm{min}$ for different passage time $(5,10,15,20,30,40,60,80,100,120,140,160$, $180 \mathrm{~min})$ at room temperature. PDMS flow cells were filled with $200 \mu \mathrm{l} \mathrm{TSB}$. After $12 \mathrm{~h}$ of incubation at $37^{\circ} \mathrm{C}$, the yield of biofilm were evaluated using plate counts (CFU) and Crystal Violet (CV) staining as mentioned above. 


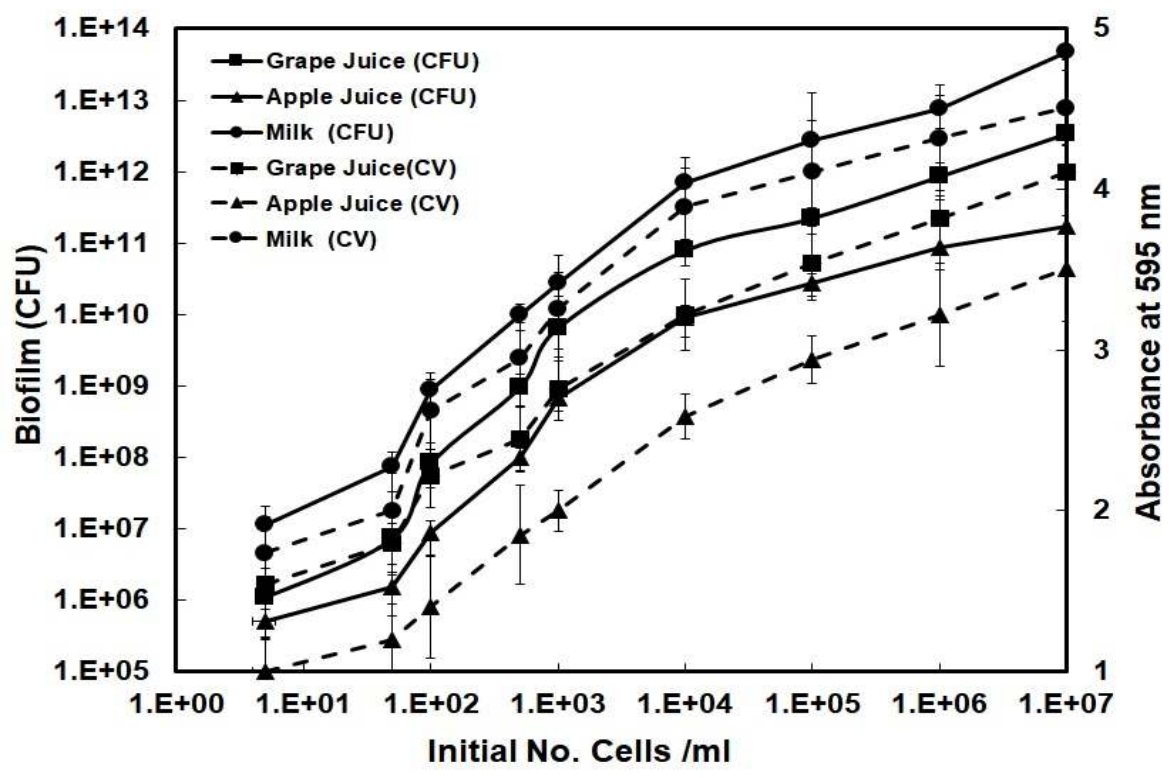

Fig. 8. bacterial adhesion capacity with different number of E.coli $0157: H 7$ cells suspended in food fluids

Different number of E. coli O157:H7 cells inoculated into different sterile food fluids was each passed through the mini-fluidic chips via the bio-Ferrograph at $0.1 \mathrm{ml} / \mathrm{min}$ for a constant passage time of $100 \mathrm{~min}$ at room temperature. PDMS flow cells were filled with $200 \mu \mathrm{l}$ TSB. After $12 \mathrm{~h}$ of incubation at 37C, the yield of biofilm were evaluated using plate counts (CFU) and Crystal Violet (CV) staining as mentioned above.

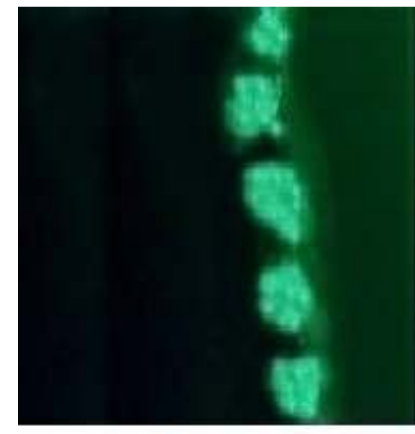

Milk

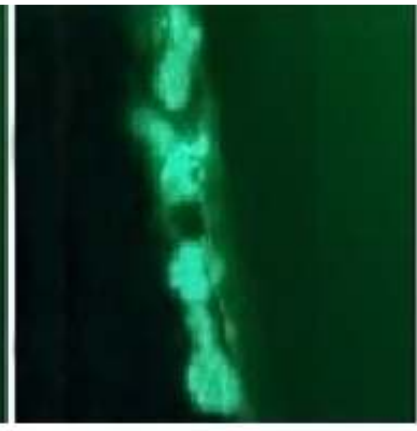

Apple Juice Grape Juice

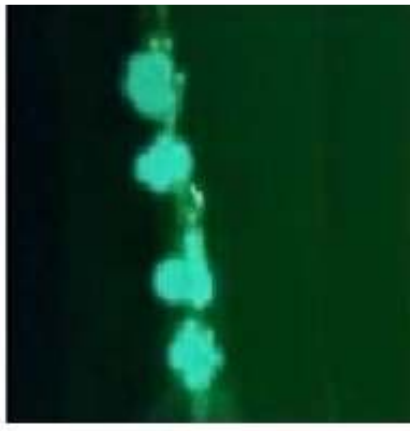

\section{Fluorescent Imaging of Biofilm}

Fig. 9. Fluorescence imaging of biofilm formation

Food fluids seeded with $1 \times 10^{4}$ cells/m/ was subjected to PDMS flow cells for $100 \mathrm{~min}$ via the bio-Ferrograph at $0.1 \mathrm{ml} / \mathrm{min}$ as mentioned above. After $12 \mathrm{~h}$ of incubation at $37 \mathrm{C}$, PBS buffer containing $4 \mathrm{mg} / \mathrm{ml}$ hyaluro nidase was pumped through the mini-channels $10 \mathrm{~min}$ at a flow rate of $0.1 \mathrm{ml} / \mathrm{min}$. PDMS chip was emptied and washed with PBS. Anti-Escherichia coli 0157:H7, FITC labeled, (1-64) was added and incubated for 60 min at 37C. Channels were washed and examined under Epifluorescence microscope using 20x lens.

these power equations would facilitate quantitative prediction of initial number of bacterial contamination in beverage pipeline. Meanwhile, the linear relationship obtained in
Fig. 7 would help to elapsed time required to adhere bacterial to the surface. This chip can be also used to quantitatively detect biofilm forming bacteria in environmental samples with the 
assessment of initial number of bacterial cells added to the channels. This PDMS flow cell can be very beneficial to study and evaluate different models for potential risk analysis models beverage industry.

\subsection{Fluorescence Imaging of Biofilm Formation}

Biofilm formation was visually detected using Escherichia coli O157:H7 Antibody, FITC labeled. Fig. 8, shows a digital image of fluorescent imaging obtained from Epifluorescence microscope for the detection of biofilm generated from different food fluids inoculated with E. coli O157:H7.

\section{CONCLUSION}

This study introduce a novel method, based on flow chamber principle, which enables nondestructive, in situ investigation of bacteria adhesion capacity as an initial step for biofilm formation in real time under a wide range of flow rates and nutrient conditions, fluid temperature, and elapsing times. This flow device is inexpensive, simple, disposable, and easy-to-use for online real-time monitoring of biofilm formingbacteria in different beverages. This microfluidic chip provides a platform that can accurately mimic the dynamic flow conditions in beverage industry and makes the results easy to compare between groups in a similar manner in real environment.

\section{ACKNOWLEDGEMENT}

This work was supported by National Science Foundation Partnerships for International Research and Education (NSF-OISE-0530203), University of Rhode Island in Collaboration with Technical University of Braunschweig, Germany.

\section{COMPETING INTERESTS}

Authors have declared that no competing interests exist.

\section{REFERENCES}

1. Little R, Peterson R. Rules of engagement: Interspecies interactions that regulate microbial communities. Annual Review of Microbiol. 2008;62:375- 401. DOI:10.1146/annurev.micro.030608.10142 3
2. Verran J, Jones M. Problems of biofilm in the food and beverage industry. In: Walker J, Suramn S, Jass J, editors. Industrial Biofouling. Cichester, N.Y.: John Wiley.I. 2000;145-173.

3. Rodríguez AS, McLandsborough LA. Evaluation of the transfer of Listeria monocytogenes from stainless steel and high-density polyethylene to bologna and American cheese. J. Food Prot. 2007;70: 600-606.

4. Pan Y, Breidt F, Kathariou S. Resistance of Listeria monocytogenes biofilms to sanitizing agents in a simulated food processing environment. Appl. Environ. Microbiol. 2006;72: 7711-7717.

5. Stopforth JD, Yoon Y, Barmpalia IM, Samelis J, Skandamis PN, Sofos JN. Reduction of Listeria monocytogenes populations during exposure to a simulated gastric fluid following storage of inoculated frankfurters formulated and treated with preservatives. Int. J. Food Microbiol. 2005; 99:309-319.

6. Boulange-Peterman, L. Processes of bioadhesion on stainless steel surfaces and cleanability: A review with special reference to the food industry. Biofouling. 1996;10:275-300.

7. Stopforth JD, Skandamis PN, Ashton LV, Geornaras I, Kendall PA, Belk KE, Scanga JA, Smithm GC, Sofos JN. Impact of inoculum preparation and storage conditions on the response of Escherichia coli 0157:H7 populations to undercooking and simulated exposure to gastric fluid. Appl. Environ. Microbiol. 2006;72:672-679.

8. Samelis J, Sofos JN, Kendall PA, Smith GC. Survival or growth of Escherichia coli 0157:H7 in a model system of fresh meat decontamination runoff waste fluids and its resistance to subsequent lactic acid stress. Appl. Environ. Microbiol. 2005;71:62286234.

DOI: 10.1128/AEM.71.10.6228-6234.2005

9. Ackers ML, Mahon BE, Leahy E, Goode B, Damrow T, Hayes PS. An outbreak of Escherichia coli O157:H7 infections associated with leaf lettuce consumption. J Infect Dis. 1998;177:1588-93.

10. Hilborn ED, Mermin JH, Mshar PA, Hadler JL, Voetsch A, Wojtkunski C. A multistate outbreak of Escherichia coli 0157:H7 infections associated with consumption of mesclun lettuce. Arch Intern Med. 1999;159:1758-64. 
11. Mahon BE, Ponka A, Hall WN, Komatsu K, Dietrich SE, Siitonen A. An international outbreak of Salmonella infections caused by alfalfa sprouts grown from contaminated seeds. J Infect Dis. 1997;175:876-82.

12. Besser RE, Lett SM, Weber JT, Doyle MP, Barrett TJ, Wells JG. An outbreak of diarrhea and hemolytic uremic syndrome from Escherichia coli O157:H7 in freshpressed apple cider. JAMA. 1993;269: 2217-2220.

13. Cody SH, Glynn MK, Farrar JA, Cairns KL, Griffin PM, Kobayashi J. An outbreak of Escherichia coli O157:H7 infection from unpasteurized commercial apple juice. Ann Intern Med. 1999;130:202-209.

14. Rangel JM, Sparling PH, Crowe C, Griffin PM, Swerdlow DL. Epidemiology of Escherichia coli 0157:H7 Outbreaks, United States, 1982-2002. Emerg Infect Dis. 2005;11(4):603-609.

DOI: 10.3201/EID1104.040739

15. Mungai EA, Behravesh C, Gould L. Increased outbreaks associated with nonpasteurized milk, United States, 20072012. Emerg Infect Dis. 2015;21(1):119122.

DOI: 10.3201/eid2101.140447

16. Musk DJ, Banko DA, Hergenrother PJ. Iron salts perturb biofilm formation and disrupt existing biofilms of Pseudomonas aeruginosa. Chem. Biol. 2005;12:789-796. DOI: 10.1016/j.chembiol.2005.05.007

17. Genigeorgis C. Biofilm: Their significance to cleaning in the meat sector. In: Burt, S. A. and Bauer, F. (Eds), New challenges in meat hygiene: Specific problems in cleaning and disinfection, Ecceamst, European Consortium for Continuing Education in Advanced Meat Science and Echnology. 1995;29-47.

18. Costerton JW, Cheng KJ, Geesey GG, Ladd TI, Nickel JC, Dasgupta M, Marrie TJ. Bacterial biofilms in nature and disease. Annual Reviews of Microbiology. 1997;4:435-464.

19. Marshall KC, Stout $R$, Mitchell $R$. Mechanisms of the initial events in the sorption of marine bacteria to surfaces. Journal of General Microbiology. 1971;68: 337-348.

20. Genigeorgis C. Biofilm: Their significance to cleaning in the meat sector. In: BURT, S. A. AND BAUER, F. (Eds), New Challenges in Meat Hygiene: Specific problems in cleaning and disinfection, Ecceamst, European Consortium for Continuing Education in Advanced Meat Science and ${ }^{1}$ echnology. 1995;29-47.

21. Stepanovic S, Vukovic D, Dakic I, Savic B, Svabic-Vlahovic M. A modified microtiterplate test for quantification of staphylococcal biofilm formation. J. Microbiol. Methods. 2000;40:175-179.

22. Bos R, Van der Mei HC, Busscher HJ. Physicochemistry of initial microbial adhesive interactions - its mechanisms and methods for study. FEMS Microbiol Rev. 1999;23:179-230.

23. Duddridge J, Kent CA, Laws JF. Effects of surface shear stress on the attachment of Pseudomonas fluorescens to stainless steel under defined flow conditions. Biotechnol Bioeng. 1982;24:153-164.

24. Schmid T, Panne U, Adams J, Nessner R. Investigation of biocide efficacy by photoacoustic biofilm monitoring. Water Res. 2004;38:1189-1196.

DOI: 10.1016/j.watres.2003.10.057

25. Palmer RJ. Microscopy flowcells: Perfusion chambers for real-time study of biofilms. Methods Enzymology. 1999; 310:160-166.

26. Abolmaaty A, Meyer DML. PDMS chip assay for the detection of biofilm formation. World Appl. Sci. J. 2011;13:1800-1806.

27. Menzel EJ, Farr C. Hyaluronidase and its substrate hyaluronan: Biochemistry, biological activities and therapeutic uses, Cancer Letters. 1998;131:3-11.

28. Bocci V, Muscetolla M, Naldini A, Bianchi E, Segre G. The lymphatic route - II. Pharmacokinetics of human recombinant Interferon a2 injected with albumin as a retarder in rabbits, Gen. Pharmacol. 1986; 17:93-96.

(C) 2017 Abolmaaty and Meyer; This is an Open Access article distributed under the terms of the Creative Commons Attribution License (http://creativecommons.org/licenses/by/4.0), which permits unrestricted use, distribution, and reproduction in any medium, provided the original work is properly cited.

Peer-review history:

The peer review history for this paper can be accessed here: http://sciencedomain.org/review-history/21822 